\title{
EXPERIMENTAL WOKRS
}

УДК 579.222:577.217

\section{Ю.Ю. Кондратюк ${ }^{1,2}$, М.А. Бабарик ${ }^{2}$, О.І. Корнелюк ${ }^{2}$}

${ }^{1}$ Київський національний університет імені Тараса Шевченка, вул. Володимирська, 64, Київ, 01033, Україна, e-mail: kondratyuk_yulya@ukr.net ${ }^{2}$ Інститут молекулярної біології та генетики НАН України, вул. Академіка Заболотного, 150, 03143, м. Київ-143, Україна

\section{ОПТИМІЗАЦІЯ БАКТЕРІАЛЬНОЇ ЕКСПРЕСІЇ ТИРОЗИЛ-ТРНК СИНТЕТАЗИ ССАВЦІВ ПРИ КУЛЬТИВУВАННІ ШТАМУ ESCHERICHIA COLI BL21(DE3)pLysE}

\begin{abstract}
Проведено оптимізацію умов бактеріальної експресії рекомбінантної тирозилтРНК синтетази. Досліжжено вплив концентрації індуктора синтезу цільового білка на його кінцевий вихіо $і$ встановлено оптимальний час культивування бактеріальної культури до та після додавання індуктора. Запропоновано оптимальну схему культивування штаму E. coli BL21(DE3)pLysE для досягнення високого рівня виходу рекомбінантного білка.
\end{abstract}

К $ю$ и о в $і$ с $л$ о в а: тирозил-тРНК синтетаза, бактеріальна система експресіі, оптимізація експресії.

Аміноацил-тРНК синтетази (АРСази) [КФ 6.1.1.] - ключові ферменти білоксинтезувального апарату клітини, які беруть участь в реалізації генетичної інформації та каталізують високоспецифічне аміноацилювання гомологічних транспортних РНК $[1,7]$. Крім того, еукаріотні АРСази виконують також ряд неканонічних функцій, у тому числі після протеолітичного розщеплення проявляють цитокінові активності [4]. Наявність цитокінових активностей у АРСаз відкриває перспективи для їх наступного застосування як нових біотерапевтичних препаратів.

Тирозил-тРНК синтетаза ссавців $€$ однією з найбільш вивчених АРСаз ссавців $[1,4]$. Цей фермент складається з двох структурних модулей: $\mathrm{NH}_{2}$-кінцевого каталітичного модуля та цитокінподібного СООН-кінцевого модуля - гомолога цитокіна ЕMAP II (ендотеліального та моноцитактивувального поліпептида II). Некаталітичний C-модуль цитоплазматичної TyrRS ссавців має подвійну функцію: бере участь у зв'язуванні тРНК як цис-фактор та після протеолітичного відщеплення від каталітичного кора синтетази проявляє цитокінову активність, подібну до EMAP II [5, 9]. В повнорозмірній TyrRS ссавців модулі з'єднані гнучким неструктурованим міжмодульним лінкером, який містить сигнал для протеолітичного розщеплення - амінокислотну послідовність PEST [1, 4]. До цього часу просторова

(C) Ю.Ю. Кондратюк, М.А. Бабарик, О.І̇. Корнелюк, 2009 
структура повнорозмірної TyrRS людини ще не встановлена: кристалографічні структури визначені тільки для окремих каталітичного [11] та ЕMAP II-подібного С-кінцевого модулів [10]. Для проведення структурних досліджень білків методами рентгенівської кристалографії або мультивимірної ЯМР-спектроскопії необхідні препаративні кількості білків - десятки мг. Тому для забезпечення цих досліджень необхідним $€$ використання високоефективних оптимізованих систем експресії рекомбінантних білків.

3 цією метою в даній роботі здійснено підбір оптимальних умов культивування бактеріальної культури та експресії цільового білка - TyrRS ссавців в препаративних кількостях для подальших структурних досліджень.

\section{Матеріали і методи}

В роботі використано штам-продуцент рекомбінантних білків, отриманий на основі реципієнта Escherichia coli BL21(DE3)pLysE. Штам трансформований за загальноприйнятою методикою [2] відповідним сконструйованим плазмідним вектором pET30a-59K TyrRS, у якого під контролем промотора фага T7 містяться гени, що кодують синтез цільового білка - повнорозмірної тирозил-тРНК синтетази (59K TyrRS). Генетичним маркером плазміди pET30a $є$ ген kan, що забезпечує стійкість трансформованих клітин до канаміцину.

Штам-продуцент вирощували на середовищі Luria-Bertani (LB), що містить 5 г дріжджового екстракту, 10 г триптону, 10 г $\mathrm{NaCl}$ в 1 л з додаванням антибіотика канаміцину до кінцевої його концентрації в розчині 30 мкг/мл. Культуру інкубували при температурі $37^{\circ} \mathrm{C}$ та інтенсивній аерації (130 об/хв) до досягнення нею оптичної густини 0,3-1,3 (залежно від часу культивування культури). Оптичну густину $\left(O \Gamma_{600}\right)$ визначали спектрофотометрично (спектрофотометр BioMate-5, Велика Британія) при довжині хвилі 600 нм.

Для індукції синтезу рекомбінантного білка в культуральне середовище додавали ізопропіл- $\beta$-тіогалактопіранозид (ІПТГ) до кінцевих концентрацій 0,5, 0,75, $1,0,1,25,1,5$ м М. Визначали час культивування культури до індукції $(1,2,3$ год) та після $(1,2,3,4,5,6,7$ год) індукції експресії.

Для експресії TyrRS підбирали оптимальне середовище культивування бактеріальної культури: середовище Luria-Bertani, м'ясо-пептонний агар (пептон, суміш амінокислот, $\mathrm{Na}_{2} \mathrm{CO}_{3}, \mathrm{NaCl}$ ), мінімальне середовище А (глюкоза, тіамін, біотин, $\mathrm{MgSO}_{4}, \mathrm{CaCl}_{2}, \mathrm{NH}_{4} \mathrm{Cl}, \mathrm{NaCl}, \mathrm{Na}_{2} \mathrm{HPO}_{4}, \mathrm{KH}_{2} \mathrm{PO}_{4}$, солі заліза, цинку, міді, кобальту, бору, марганцю як мікроелементи).

Рекомбінантний білок отримували із супернатанту лізованих клітин E. coli методом металхелатувальної хроматографії на Ni-NTA-агарозній колонці. Клітини руйнували ультразвуком, освітлювали лізат центрифугуванням. Супернатант наносили на колонку з Ni-NTA-агарозою (Qiagen, США). Цільовий білок елюювали буфером для елюції (50 мМ натрій-фосфатний буфер, 150 мM NaCl, 200 мМ імідазолу, 5 мМ $\beta$-меркаптоетанолу). Фракції, що містили цільовий білок діалізували.

Аналіз бактеріальних білків проводили за допомогою SDS-гель-електрофорезу по Леммлі в денатурувальних умовах (12\% розділювальний гель) [6], використовуючи суміш маркерних білків фірми Fermentas (Литва). Гелі фарбували Coomassie blue R-250. Вміст білків визначали денситометрично (денситометр LKB UltroScan $\mathrm{XL}$, Швеція). При статистичній обробці результатів дослідження використовували пакет статистичних програм STATISTICA 7.0. Одержані результати представлені у вигляді середніх значень з урахуванням середніх квадратичних відхилень. 


\section{Результати та їх обговорення}

Система експресії на основі РНК-полімерази фага Т7 - одна з найефективніших прокаріотних систем, що широко використовуються для отримання цільових продуктів як про-, так і еукаріотного походження. Вона з успіхом використовується для біосинтезу рекомбінантних білків в лабораторних умовах і в умовах великомасштабного виробництва. Найчастіше в ролі продуцента в таких системах виступає штам E. coli BL21(DE3)pLysE, спеціально для цього сконструйований [2]. В клітинах E. coli BL21(DE3) ген РНK-полімерази фага T7 під контролем lac UV5 промотора локалізується в бактеріальній хромосомі, куди він інтегрований у складі фага $\lambda$. Штам E. coli BL21(DE3) використовують як реципієнт для різних плазмідних векторів, в яких цільовий ген вбудований під контроль одного 3 промоторів, що впізнаються РНК-полімеразою фага Т7. Індукція синтезу фагового фрагмента i, як наслідок, високоефективна транскрипція цільового гену в складі рекомбінантної плазміди спостерігаються після додавання в середовище культивування індуктора - ІПТГ [3, 8].

Важливим моментом на етапі внесення в культуральне середовище індуктора синтезу цільового білка $є$ час його додавання, адже від стадії росту, на якій знаходиться бактеріальна культура, залежить синтез потрібного продукту. Оптимальним $€$ час, коли культура знаходиться в логарифмічній фазі росту.

Нами досліджено рівень експресії білка 59K TyrRS залежно від кількості ІПТГ та часу культивування бактеріальної культури до індукції. Як видно з рисунка 1, при підвищенні концентрації індуктора до 1 мМ спостерігалося чітке зростання рівня експресії білка. При подальшому збільшенні кількості ІПТГ така тенденція втрачалася і навпаки відмічався спад рівня експресії.

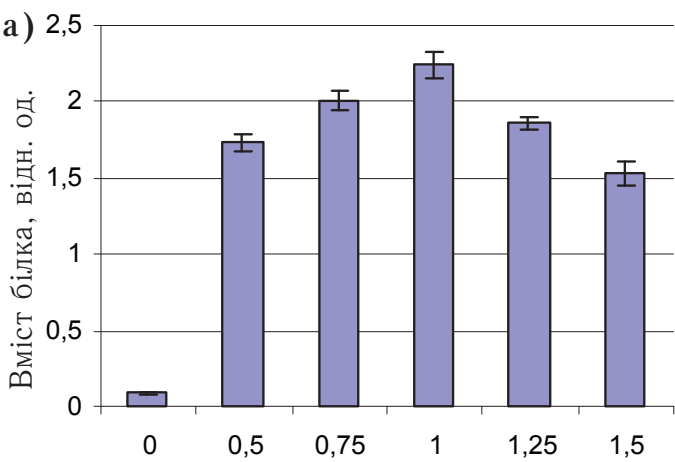

б)

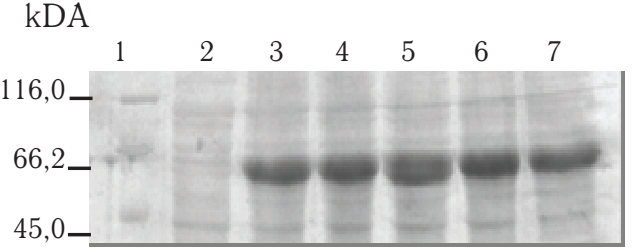

Концентрація індуктора, мМ

Рис. 1. Рівень експресії білка 59K TyrRS залежно від концентрації ІПТГ: а) залежність виходу білка від концентрації індуктора; б) електрофореграма білків, отриманих при додаванні різної кількості ІПТГ. 1 - білкові маркери молекулярної маси ("Fermentas”, Литва); 2 - лізат до індукції; 3-7 - лізати після індукції (0,5 мМ, 0,75 мМ, 1 мМ, 1,25 мМ, 1,5 мМ ІПТГ, відповідно).

Fig. 1. The expression level of $59 \mathrm{~K}$ TyrRS protein depending on the IPTG concentration: a) the dependence of protein output upon concentration of inductor; b) electrophoregrams of proteins, obtained by adding different amount of IPTG. 1 - protein molecular weight markers ("Fermentas", Lithuania), 2 - without inducer; 3-7 - induced with 0,5 mM, 0,75 mM, $1 \mathrm{mM}, 1,25 \mathrm{mM}, 1,5 \mathrm{mM}$ IPTG respectively. 
Максимальна кількість білка спостерігалася за умови додавання в середовище культивування індуктора на другу годину росту культури $\left(\mathrm{O} \Gamma_{600}=0,7-0,9\right)$, шо пояснюється імовірним досягненням культурою найбільш сприятливої фази росту (рис. 2):

a)

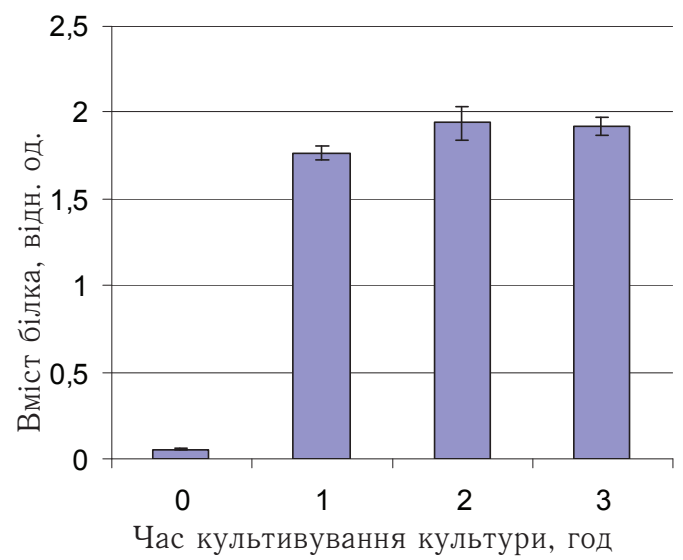

б)

$\mathrm{kDA}$

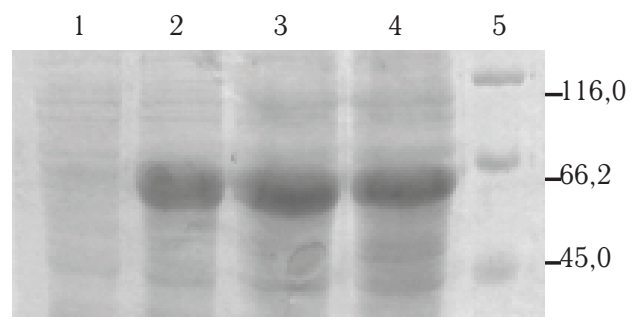

Рис. 2. Рівень експресії білка $59 \mathrm{~K}$ TyrRS залежно від часу культивування бактеріальної культури до індукції: а) залежність виходу білка від часу культивування; б) електрофореграма білків, отриманих за різного часу культивування.

1 - лізат до індукції; 2-4 - лізати після індукції (1, 2, 3 год культивування до індукції, відповідно); 5 - білкові маркери молекулярної маси (“Fermentas”, Литва).

Fig. 2. The level of expression of $59 \mathrm{~K}$ TyrRS protein depending on the time of bacterial culture cultivation to induction: a) the dependence of protein output of cultivation time; b) electrophoregrams of proteins, obtained at different time of cultivation. 1 - without inducer; $2-4-$ after induction $(1,2,3$ h of cultivation with inductor, respectively); 5 - protein molecular weight markers ("Fermentas", Lithuania).

При дослідженні рівня експресії білка залежно від часу культивування культури після індукції показано найбільший приріст експресії цільового білка при культивуванні культури протягом 4 год. При подальшому культивуванні спостерігали незначне зростання біосинтезу білка 59K TyrRS та збільшення синтезу бактеріальних білків (рис. 3).

Накопичення в біомасі клітин цільового продукту при культивуванні рекомбінантних штамів-продуцентів залежить не лише від генотипових властивостей популяції рекомбінантних клітин, а також великою мірою обумовлене якістю та кількістю субстратів. Вдало підібране ростове середовище дозволяє досягати високих рівнів виходу цільових білків. 


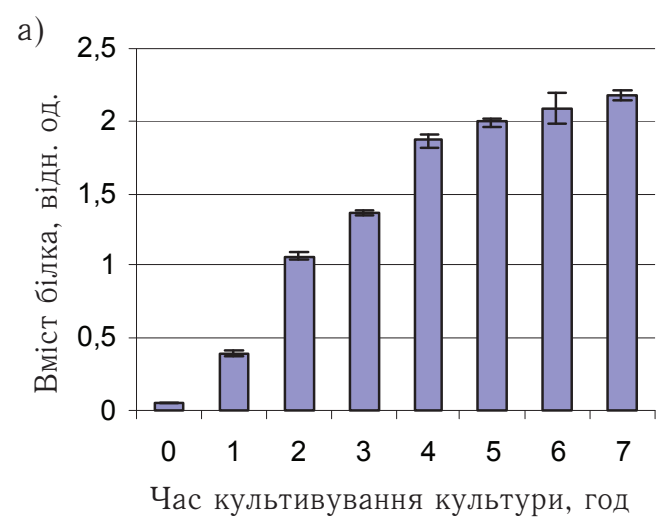

б)

$\mathrm{kDA}$

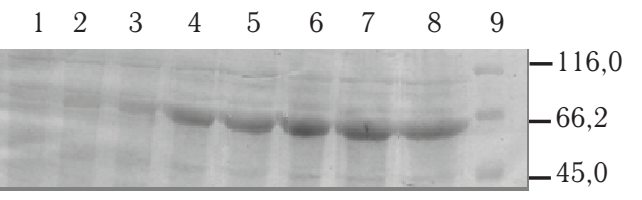

Рис. 3. Рівень експресії білка 59K TyrRS залежно від часу культивування культури після індукції: а) залежність виходу білка від часу культивування;

б) електрофореграма білків, отриманих за різного часу культивування.

1 - лізат до індукції; 2-8 - лізати після індукції $(1,2,3,4,5,6,7$ год культивування після індукції, відповідно); 9 - білкові маркери молекулярної маси ("Fermentas", Литва).

Fig. 3. The level of expression of $59 \mathrm{~K}$ TyrRS protein depending on the time of cultivation of bacterial culture after induction:

a) the dependence of protein output of cultivation time; b) electrophoregrams of proteins, obtained at different cultivation time.

1 - without inducer; 2-8-after induction $(1,2,3,4,5,6,7$ h of cultivation with inductor, respectively); 9 - protein molecular weight markers ("Fermentas", Lithuania).

При культивуванні бактеріальної культури на різних поживних середовищах встановили, що найвищий рівень експресії білка 59K TyrRS спостерігався при вирощуванні на мінімальному середовищі А, що пояснюється наявністю в ньому тіаміну, біотину та мікроелементів (рис. 4).

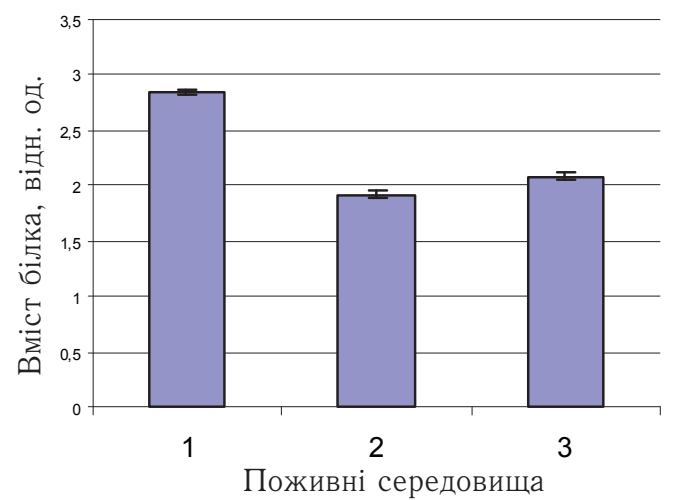

Рис. 4. Рівень експресії білка 59K TyrRS залежно від середовища культивування бактеріальної культури: 1 - мінімальне середовище A; 2 - LB; 3 - МПА.

Fig. 4. The level of expression of $59 \mathrm{~K}$ TyrRS protein depending on cultivation medium: 1 - minimal medium A, 2 - LB, 3 - beef-extract agar.

Проведено бактеріальну експресію та афінну очистку білка 60kTyrRS. Отримано необхідну для подальших досліджень кількість даного білка високого ступеня чистоти (рис. 5). 


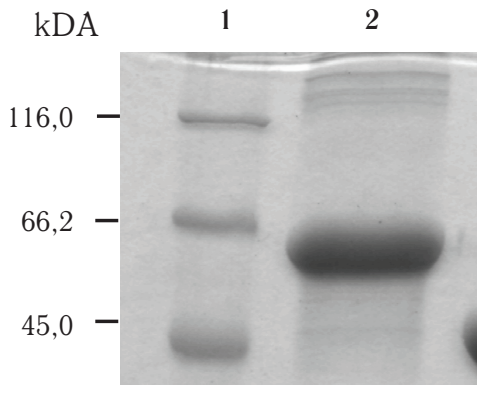

\author{
Рис. 5. Електрофоретичний контроль чистоти \\ білків ( $12 \%$ розділювальний гель): \\ 1 - білкові маркери молекулярної маси \\ (“Fermentas”, Литва), 2 - білок 59K TyrRS.
}

\section{Fig. 5. Electrophoregrams of protein purity} control (SDS-12\% PAGE):

1 - protein molecular weight markers ("Fermentas", Lithuania), 2 - protein 59K TyrRS.

Отже, в результаті досліджень здійснено оптимізацію бактеріальної експресії повнорозмірної тирозил-тРНК синтетази ссавців. Встановлено, що оптимальна кількість індуктора IПТГ для експресії TyrRS ссавців становить 1 мM, а час культивування бактеріальної культури до та після індукції синтезу цільового білка становить дві та чотири години, відповідно. Вихід цільового білка - TyrRS ссавців - при бактеріальній експресії в культурі клітин E. coli BL21(DE3)pLysE складає 68,52 мг $з 1$ л культуральної рідини, що відповідає 29\% сумарних бактеріальних білків. Отриманий вихід білка $є$ достатнім для проведення наступних структурних досліджень TyrRS ссавців фізичними методами: рентгеноструктурним аналізом та ЯМР-спектроскопією.

\section{ЛІТЕРАТУРА}

1. Корнелюк А.И. Структурно-функциональное исследование тирозил-тРНК синтетазы млекопитающих // Биополимеры и клетка. - 1998. - Т. 14, № 4. - С. 349-359.

2. Маниатис Т., Фрич Ә., Сэмбрук Дж. Методы генетической инженерии. Молекулярное клонирование. - М.: Мир, 1984. - 479 с.

3. Славченко И.В., Борейко Е.В. Фенотипическое проявление особенностей метаболизма клеток Escherichia coli BL 21(DE3) при выращивании на средах, содержащих разные источники углерода // Біополімери і клітина. - 2002. - Т. 18. - № 3. - С. 232-236.

4. Ivakhno S. S., Kornelyuk A. I. Cytokine-like activities of some aminoacyl-tRNA synthetases and auxiliary p43 cofactor of aminoacylation reaction and their role in oncogenesis // Exper. Oncol. - 2004. - V. 26. - P. 250-255.

5. Kornelyuk A.I., Tas M.P., Dubrovsky A.L., Murray J.C. Cytokine activity of the noncatalytic EMAP-2-like domain of mammalian tyrosyl-tRNA synthetase // Biopolimery i kletka. - 1999. - V. 15, № 2. - P. 168-172.

6. Laemmli U.K. Cleavage of structural proteins during the assembly of the head of bacteriophage T4 // Nature. - 1970. - V. 277, № 259, - P. 680-685.

7. Schimmel $P$. Aminoacyl-tRNA synthetase: general features and recognition of transfer RNAs // Ann. Rev. Biochem. - 1987. - V. 56. - P. 125-158.

8. Studier F.W., Moffatt B.A. Use of bacteriophage T7 RNA polymerase to direct selective high-level expression of cloned genes // J. Mol. Biol. - 1986. - V. 189D, № 1. - P. 113-130.

9. Wakasugi K., Schimmel P. Two distinct cytokines released from a human aminoacyltRNA synthetase // Science. - 1999. - V. 284. - P. 147-151.

10. Yang X.L., Liu J., Skene R.J., McRee D. and Schimmel P. Crystal Structure of an EMAP-II-Like Cytokine Released from a Human tRNA Synthetase // Helvetica Chimica Acta 2003. - V. 86. - P. 1246-1257.

11. Yang X.L., Skene R.J., McRee D.E., Schimmel P. Crystal structure of a human aminoacyltRNA synthetase cytokine // Proc. Natl. Acad. Sci. U.S.A. - 2002. - V. 99, № 243. - P. 1536915374 . 
Ю.Ю. Кондратюк ${ }^{1,2}$, М.А. Бабарык ${ }^{2}$ А.И. Корнелюк ${ }^{2}$

${ }^{1}$ Қиевский национальный университет имени Тараса Шевченка,

ул. Владимирская, 64, Киев, 01033, Украина, e-mail: kondratyuk_yulya@ukr.net ${ }^{2}$ Институт молекулярной биологии и генетики НАН Украины, ул. Академика Заболотного, 150, 03143, г. Киев-143, Украина

\section{ОПТИМИЗАЦИЯ БАКТЕРИАЛЬНОЙ ЭКСПРЕССИИ ТИРОЗИЛ-ТРНК СИНТЕТАЗЫ МЛЕКОПИТАЮЩИХ ПРИ КУЛЬТИВИРОВАНИИ ШTAMMA ESCHERICHIA COLI BL21 (DE3) pLysE}

\section{Рeферат}

Проведена оптимизация условий бактериальной экспрессии рекомбинантной тирозил-тРНК синтетазы. Исследовано влияние концентрации индуктора синтеза целевого белка на его конечный выход, а также установлено оптимальное время культивирования бактериальной культуры до и после добавления индуктора. Предложена оптимальная схема культивирования культуры E. coli BL21 (DE3) pLysE для достижения высокого уровня выхода рекомбинантного белка.

К л ю ч е в ы е с л о в а: тирозил-тРНК синтетаза, бактериальная система экспрессии, оптимизация экспрессии.

\section{Yu.Yu. Kondratiuk ${ }^{1,2}$, M.A. Babaryk ${ }^{2}$, O.I. Kornelyuk ${ }^{2}$}

${ }^{1}$ National Taras Shevchenko University of Kyiv, Volodymyrska str., 64, Kyiv, 01033, Ukraine, e-mail: kondratyuk_yulya@ukr.net

${ }^{2}$ Institute of Molecular Biology and Genetics of NASU, Zabolotny str., 150, Kyiv-143, 03143, Ukraine

\section{BACTERIAL EXPRESSION OPTIMIZATION OF MAMMALIAN TYROSYL-tRNA SYNTHETASE ON STRAIN ESCHERICHIA COLI BL21 (DE3) pLysE CULTIVATION}

\section{Summary}

The optimization of the conditions of bacterial expression of recombinant tyrosyltRNA synthetase was conducted. The influence of the concentration of synthesis inductor of target protein at its final output and the best time of cultivation of bacterial culture before and after inductor adding was investigated. The optimal conditions for culture E. coli BL21 (DE3) pLysE cultivation to achieve a high expression level of recombinant protein were proposed.

K e y w o r d s: tyrosyl-tRNA synthetase, bacterial expression system, optimization of expression. 